\title{
Eco-friendly Holi using Natural Dye and Low Cost Filler Base
}

\author{
Puja Basumatary*, Manoj Kumar Bhuyan, Porna Sarmah and Dipangka Saikia
}

Krishi Vigyan Kendra, Kokrajhar, Assam Agricultural University, Gossaigaon, Assam, India

*Corresponding author

Holi, a great festival organized by Hindu culture aims to enjoy nature with the natural way. It makes everyone crazy and behaves like a child, and resultant we come close to nature. It is celebrated in every spring on the full moon day of the month Phalguna (FebruaryMarch). Men, women and children, regardless of age or wealth, enjoy this festival of color showing "unity in diversity". Traditionally 'Holi' was use to be made of natural colored powders having medicinal significance. But now a day the chemical colors have been diverted this natural instinct of the fest and many safety issues have been found in all three forms of synthetic colors produced i.e., pastes, dry colors and water colors which are prepared from harmful substances like metal oxide, acids, mica, glass powder, alkalis, sand, soil, silica, asbestos, chalk etc. and are quite capable of causing serious skin complications and allergies. Nowadays often referred as unholy colors of 'Holi', artificial colors can lead to skin allergies, irritation, redness, rashes, itching, bumps and also proving a risk to an environment due to the toxic colors used in holi. This makes the fest less charming in comparison with holi celebrated in earlier days with natural colours. By advocacy of natural and eco-friendly colors, only a little to no effort to gain its ecofriendly approach is done. Thus this paper aims to recover the healthy point of view for celebrating holi by using safe, natural and eco friendly holi made by natural dye extracted from plant material containing tapioca and compared with rice flour holi containing natural dye and commercial chemical holi.

\section{Introduction}

'Holi' the festival of colour, fun, joy and harmony and is an ancient festival of India and was originally known as 'Holika'. Holi is also called festival of love and celebrated by splash of scanted colors over each other, wearing new clothes preferably white and feast of delicious dishes as sweets and juice especially 'lassi' etc are rituals of the festival. In ancient time colors for Holi were prepared from the various parts of trees such as flowers, leaves, fruits etc. Some of them are Indian coral tree (Parijat), flame of forest (Kesu), marigold, turmeric (Haldi), henna (Mahandi), neem, sandalwood, beetroot etc. Turmeric, neem, sandalwood, tesu flower was $100 \%$ natural and have beneficial healing properties as per ayurveda. In modern time, with the arrival of dry chemical colors, people stopped taking pence for extracting the flowers colors and the use of chemical colors 
in holi is increasing day by day. Holi colours are available in three different forms i.e., paste, dry and wet colours. To get darker, long lasting colours and thick texture industrial dyes and metal oxides mixed with low quality engine oil (for Paste) are used in holi. The synthetic dye based holi powder can cause dermatitis, respiratory problems and allergies and prolong application can cause cancer (Das et al., 2015). Moreover, scientific test have verified that this can cause skin abrasions, skin and eye irritation, allergy and can even triggers asthma (Rawat, 2008; Sarmah and Sexena, 2013 and Sarmah A, 2013). Similarly, dry colours are deadly combination of toxic heavy metals which disrupts metabolic functions of body and build up in the body's vital organs such as the kidneys, lung and bones, and a filler base asbestos, chalk or silica. The colorant used in the dry colors, also called gulals, was found to be toxic, with heavy metals causing asthma, skin diseases and temporary blindness (Toxics link, 2000). These chemical colors are not only extremely dangerous to skin but also are hazardous for environment (Sarmah and Saxena, 2013). For wet colours, water based colour are used which get easily dissolved in water. One of the common and easily available water colorant in Gentian violet, it is highly toxic and hazardous to human health. It leads to severe skin ailments and eye problem (Table 1).

A recent study conducted under the National Biodiversity Strategy and Action Plan revealed that chemical colors have all but wiped out India's wonderful vegetable dyes (Chaube et al., 2010). Chemical colors give delightful pleasure to eyesight but at the same time may act as serious pollutants. In India, these colors are prepared on a small scale and lack any quality checks (Gardner and Lal, 2012). Whereas, Natural dyes/colorants derived from flora and fauna are believed to be safe because of its nontoxic, non- carcinogenic and biodegradable in nature (Cristea and Vilarem, 2003). Ahlstrom et al (2005) also quoted that natural dyes are environmental friendly, exhibit better biodegradability and generally have a higher compatibility with the environment than synthetic dyes. The process is economically viable as the raw materials are available at low cost and so cost of production is also very low. Similar findings were reported in Marigold, China rose and Bixa flower (Ibrahim et al., 1997). Many tribes of Arunachal Pradesh have been using this plant species traditionally in combination with other plants for extraction and preparation of dyes utilizing indigenous processes (Mahanta and Tiwari, 2005). Natural dyes are now a days in demand not only in textile industry but in cosmetics, leather, food and pharmaceuticals. The rich biodiversity of our country has provided us plenty of raw materials, yet sustainable linkage must be developed between cultivation, collection and their use (Gokhale et al., 2004). Hence, the present study was conducted to evaluate the potentiality of eco friendly holi prepared by using natural dyes extracted from plants which is not only safe to human health but will also have zero risk to the environment, with low cost filler base such as Tapioca (Manihot esculenta) flour as a substitute for costly starch extracted from corn and other cereals, asbestos or silica which is associated with health issues.

\section{Materials and Methods}

The present study was conducted at Krishi Vigyan Kendra, Kokrajhar, A.A.U, Gossaigaon during the year 2019-20. Two types of Filler base viz. Tapioca Flour and Rice flour was used to prepare natural and eco friendly holi. Both raw tubers of tapioca and rice were collected from K.V.K, Kokrajhar farm. 


\section{Preparation of filler base}

Raw tubers of tapioca were made into flour following standard method by Das et al., 2008. In this method, raw tapioca tubers were collected; the skin was peeled off and washed properly. After washing, the tubers were made into thin slices of around $2 \mathrm{~mm}$ thickness with the help of chipping machine. Slices can be of any shape round or thin matchsticks. The slices were then dried under sun over clean surface. Depending upon the availability of bright sun shine hours it will take 5-7 days and when dried slices will break easily (Moisture content 10\%) when pressed under finger. These dried chips are grounded in hammer mill and sieved with a mesh size of 250 micron to obtain tapioca flour. The flour produced from tapioca can also be made into different group of baked products, gelatinized products or manufactured into glucose, dextrin and other products.

Whereas, to get rice flour wet grinding method by Yeh (2004) was followed. In this method, one and half kilogram $\left(1 \frac{1 / 2 \mathrm{~kg}}{)}\right.$ of the rice were soaked in $3000 \mathrm{ml}$ of water for $4-5$ hours at $30^{\circ} \mathrm{C}$, milled in excess of water using a wet grinder, dried in a hot air, oven at $40^{\circ} \mathrm{C}$ overnight, reground and sieved with a mesh size of 250 micron to obtain rice flour.

\section{Extraction of natural dyes}

Dyes are one of the most important uses of the plants and plant parts. Recently, the interest in use of natural dyes has been growing rapidly due to toxic and allergic reactions associated with the use of synthetic dyes and the stringent environmental standards imposed by many countries in response to use of synthetic dyes. As a result with a distinct lowering in synthetic dyestuff costs, the natural dyes were virtually unused at the beginning of twentieth century (Kumaresan et al., 2011). Nowadays, most of the countries were using synthetic dyes in all commercial dyeing processes and natural dyeing was left to be practiced only as a handcraft. However, with the worldwide concern over the use of eco-friendly and biodegradable materials, the use of natural dyes has once again gained interest (Agarwal et al., 1992).

For this study, the natural dyes were extracted from spinach, orange marigold and turmeric through traditional aqueous extraction process as described by Yusuf (2018). Briefly materials containing dye was first broken into small pieces, dried, powdered and sieved to improve extraction efficiency. It is then soaked with water in metal vessels (stainless steel) for overnight to loosen the cell structure and then boiled to get the dye solution, which is filtered to remove non dye plant remnants. The process of boiling and filtering is repeated to remove as much dye as possible. After the dye is extracted it is stored in the refrigerator for further use (Table 2).

\section{Extraction of fragrance compound/ essential oil}

Essential oils are highly concentrated substances, which are extracted from fruit peels, flowers, leaves, stems, roots and seeds. These oils are often used for their flavor and their therapeutic or odiferous properties, in wide selection products such as foods, pharmaceuticals, medicines, perfumery industry and cosmetics. Essential oils are generally derived from one or more plant parts, such as flowers (e.g. rose, jasmine, carnation, clove, mimosa, rosemary, lavander), leaves (e.g. mint, Ocimum spp., lemongrass, jamrosa), leaves and stems (e.g. geranium, patchouli, petitgrain, verbena, cinnamon), bark (e.g. cinnamon, cassia, canella), wood (e.g. cedar, sandal, pine), roots (e.g. angelica, sassafras, vetiver, saussurea, valerian), seeds (e.g fennel, coriander, 
caraway, dill, nutmeg), fruits (bergamot, orange, lemon, juniper), rhizomes (e.g. ginger, calamus, curcuma, orris) and gums or oleoresin exudations (e.g. balsam of Peru, Myroxylon balsamum, storax, myrrh, benzoin) Tembe et al., 2018.

For extraction of fragrance compound Orange peel was used. Since the oil sac present in the peel contain majority of oil. Orange peel is used for extraction of essential oil. After the orange peels were obtained, they were washed, cleaned with water and chopped into small pieces.

The pieces were then placed thinly on clean surface and dried under shade or at room temperature for 5 days. The shade dried orange peels were grinded into fine powder using electrical grinding machine. The powdered orange peels was then stored in air tight container away from direct sunlight.

\section{Hydro distillation method (Meyer-Warnod et al., 1984)}

For extraction of essential oil hydro distillation method was followed. It is one of the oldest and easiest methods used for the extraction of essential oils. This method consists of distillation flask, Basket heater, horizontal condenser and a conical flask. About $150 \mathrm{~g}$ of the orange peel powder was weighed using digital weighing balance and transferred into a round bottom flask with water to cover the peels.

The flask was connected to the still column which was connected to the condenser. Heat is supplied to the distillation unit by temperature controlled basket heater and the mixture is brought to boil. Tsegaye et al., (2019) observed maximum essential oil yield of $4.5 \mathrm{ml}$ at extraction temperature of $100^{\circ} \mathrm{C}$ and extraction time of $180 \mathrm{~min}$ and reported that increase in extraction temperature and time leads to a corresponding increase in essential oil yield. The oil will eventually break out of the peel matrix and thus be extracted. The heat and steam burst and break the cell structure and evaporate the essential oil. These steams are carried along a pipe and channeled through condenser and the distillate is collected in a conical flask in a liquid form.

The emerging liquid is a mixture of oil and water and has two layers, one dense and other less dense layer which is then separated using a separating funnel since water is denser than oil and it is collected at the bottom of the funnel. When the funnel tap is opened the liquid at the bottom of the funnel is collected and transferred into a container.

\section{Preparation of Natural Holi}

Aqueous solution of natural dye (green, orange and yellow) extracted from plant parts of spinach, orange marigold and turmeric were mixed uniformly with tapioca $(10 \%$ moisture content) and rice flour $(10 \%$ moisture content) in the ratio $1: 1(\mathrm{w} / \mathrm{v})$ and was made into dough by manual kneading. Fragment compound extracted from orange peel was also added to the coloured natural holi so as to attract the customer preference. This dough is manually spread with thickness of about $1 \mathrm{~cm}$ over plastic sheet or any other clean surface and exposed to sun drying till the moisture content reached less than $10 \%$ (wet basis). The dried material was then milled in a hammer mill and sieved through 250 micron sieve to get the 'holi' powder and to avoid any bacterial and fungal spoilage which in turn reduces the shelf life.

\section{Packaging of the Natural Holi}

Prepared Natural Holi was packed air tight in dual layer Poly Propylene bags by machine sealing (using Sepack 200dv2) to avoid outer air contact and spoilage. 
Assessment for preference of Natural dye holi against commercial holi

Two group of participants (A \& B) of 20 members each comprising of KVK, Officials and nearby identified farmers/ entrepreneurs were selected for the purpose. Both group were subjected to three types of Holi (Commercial, Natural holi with Rice Flour and Tapioca flour as filler base) representing the same colour variants in triplicate (presented in Fig.1). Before the test Group A was informed well about the types of Holi (labelled) and asked to put their remarks on their preference. Whereas Group B was completely unaware of the types of holi presented before them and asked for their preferences. The 'holi' powder of three different shades was scored for overall acceptable and preference as 'holi' powder, texture and colour preferences, gender preference to colour between natural holi and commercial holi of same shades.

The assessment was done by using nine point Hedonic scale just after making natural dye holi. All the information and data gathered were combined and summarized in tabular form using Microsoft Excel, 2013. The statistical analyses were performed using
Statistical Package for Social Sciences (SPSS) version 25.0 for Windows.

\section{Results and Discussion}

Overall acceptance and preference as 'holi' powder, texture, colour preferences and gender preference to colour to three different types of holi was analyzed between Group A and Group B. It was observed from the table no. 3 that seventy percent of Group A chooses tapioca flour holi over rice flour holi (32\%) with natural dye. None of the group members preferred commercial holi after learning its harmful effects. From Group B, sixty two percent preferred tapioca flour holi as compare to thirty three percent rice flour holi. Only five percent of people choose commercial holi over tapioca and rice flour holi.

In terms of preference to texture fifty two percent of Group A members preferred tapioca flour holi to forty three percent of rice flour holi and only five percent preferred the texture of commercial holi. Similarly in case of group B forty seven percent preferred tapioca flour holi to forty five percent rice flour holi with only eight percent preference to commercial holi.

Table.1 Chemical used in holi colours and its effects on health

\begin{tabular}{|l|l|l|}
\hline Colour & Chemical used & \multicolumn{2}{|c|}{ Effects on health } \\
\hline Red & Mercuric oxide & Can cause skin cancer \\
\hline Pink & Rhodamine B & $\begin{array}{l}\text { Skin and respiratory tract irritation, ingestion may cause } \\
\text { gastrointestinal irritation with nausea, vomiting and diarrhea }\end{array}$ \\
\hline Blue & Prussian blue & Cause dermatitis \\
\hline Black & Lead & Cause renal failure, toxic for children, affects unborn child \\
\hline Orange & Chromium Iodine & Bronchial asthma, allergies \\
\hline Yellow & Auramine & Carcinogenic in nature \\
\hline Green & Copper sulphate & Affects eyes, skin, respiratory system, liver and kidneys \\
\hline Silver & Aluminium Bromide & Carcinogenic in nature \\
\hline Filler Base & Silica & Skin dries and chaps \\
\cline { 2 - 3 } & Asbestos & Carcinogenic in nature \\
\cline { 2 - 3 } & Chalk & Can enter and affect human respiratory system \\
\hline
\end{tabular}


Table.2 List of plants and plant parts used for extraction of natural dye

\begin{tabular}{|l|l|}
\hline Colour & Plants/ Plant parts \\
\hline Red & $\begin{array}{l}\text { Hibiscus flower (dried), Daylilies (old blooms), Portulaca flowers (dried ), Red rose, } \\
\text { Red sandal wood powder, Annato seed (Sindur), Shimul, Krishnachura, Maddar root. }\end{array}$ \\
\hline Orange & $\begin{array}{l}\text { Dried flower of flame of forest, Orange marigold, carrot } \\
\text { Green leafy vegetables such as loffa, spinach, dhatura leaves extract etc and } \\
\text { condiments such as coriander, mint, papaya leaves. }\end{array}$ \\
\hline Yellow & $\begin{array}{l}\text { Turmeric, Yellow Marigold, Yellow chrysanthemum, Amaltas, Black Babul, dried } \\
\text { rind of bael, grass, peach (leaves), Hydrangea (flowers) }\end{array}$ \\
\hline Blue & $\begin{array}{l}\text { Dried flower of neeli, gulmohar, indigo flower, mulberries, red cabbage, hyacinth } \\
\text { (flowers) }\end{array}$ \\
\hline Violet/Pink & Beetroot, Onion peel, pink flower of Kanchan, raspberries, cherries, strawberries, \\
\hline Purple & Black Jamun \\
\hline Brown & $\begin{array}{l}\text { Heena powder with amla powder (one part of heena powder with 4 parts of amla), } \\
\text { Dandelion (roots), hollyhock (petals), pine tree bark, tea leaves. }\end{array}$ \\
\hline
\end{tabular}

Table.3 Analysis of two different groups for natural and chemical holi

\begin{tabular}{|l|l|l|l|l|l|l|l|}
\hline S1. No. & Particulars & \multicolumn{4}{|c|}{ Group A } & \multicolumn{3}{c|}{ Group B } \\
\cline { 3 - 8 } & & $\begin{array}{l}\text { Natural holi } \\
\text { with Tapioca } \\
\text { flour as filler } \\
\text { base }\end{array}$ & $\begin{array}{l}\text { Natural } \\
\text { holi with } \\
\text { Rice flour } \\
\text { holi as } \\
\text { filler base }\end{array}$ & $\begin{array}{l}\text { Commercial } \\
\text { chemical holi }\end{array}$ & $\begin{array}{l}\text { Natural } \\
\text { holi with } \\
\text { Tapioca } \\
\text { flour as } \\
\text { filler base }\end{array}$ & $\begin{array}{l}\text { Natural holi } \\
\text { with } \\
\text { flour holi as } \\
\text { filler base }\end{array}$ & $\begin{array}{l}\text { Commercial } \\
\text { chemical holi }\end{array}$ \\
\hline 1. & $\begin{array}{l}\text { Overall acceptance } \\
\text { and preference as } \\
\text { 'holi' powder }\end{array}$ & $70 \%$ & $30 \%$ & $0 \%$ & $62 \%$ & $33 \%$ & $5 \%$ \\
\hline 2. & Texture & $52 \%$ & $43 \%$ & $5 \%$ & $47 \%$ & $45 \%$ & $8 \%$ \\
\hline
\end{tabular}

Fig.1 Assessment for preference of Natural dye holi against Commercial holi (CH- Commercial Holi, RFH- Rice Flour Holi, TPH- Tapioca Flour Holi

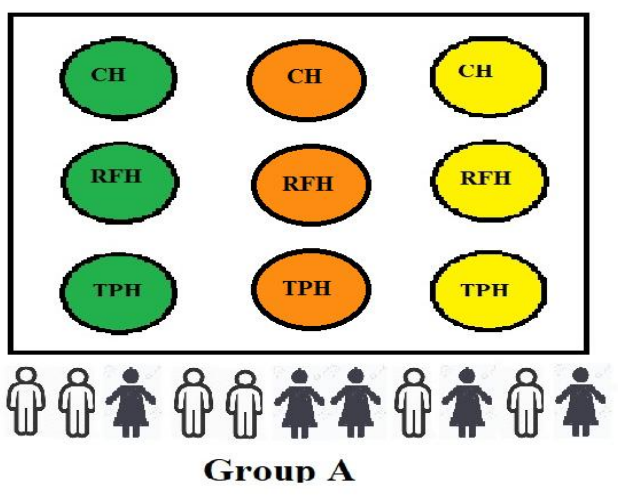

Group A

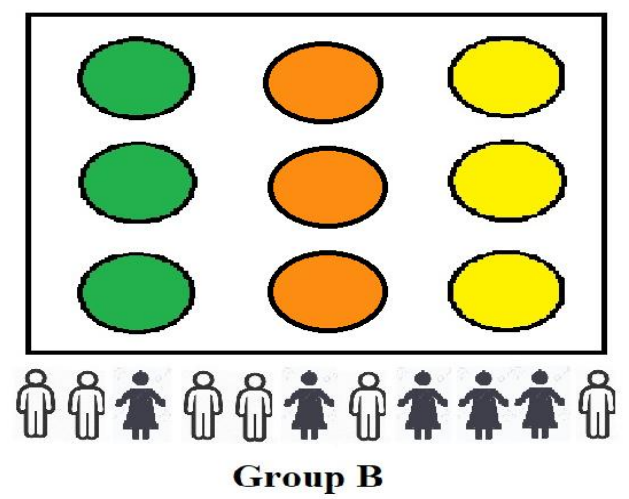

Group B 
Fig.2 Pie chart depicting colour preferences by two group
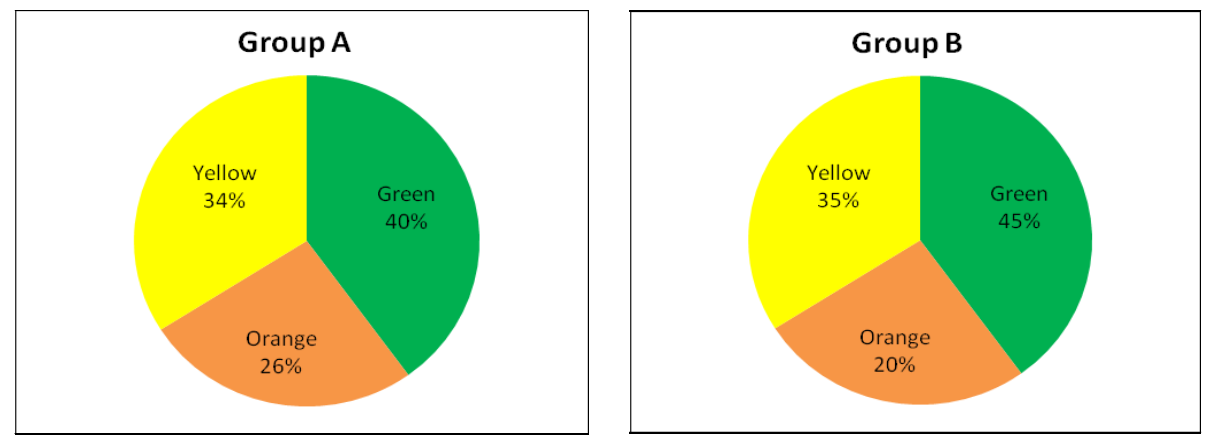

Fig. 2 Pie chart depicting colour preferences by two group

Fig.3 Histogram depicting gender preferences to colour between two group
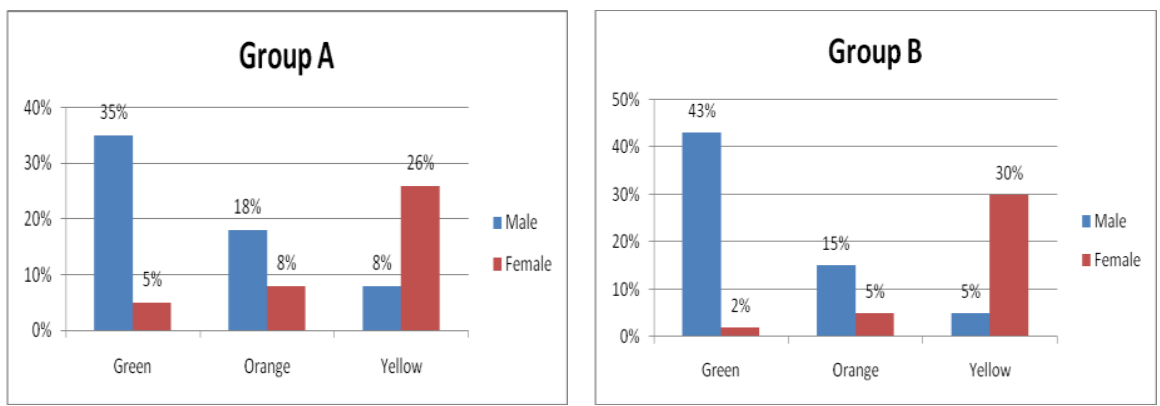

Fig. 3 Histogram depicting gender preferences to colour between two group

Fig.4 Eco-friendly holi with natural dye and tapioca flour as filler base of three different shades
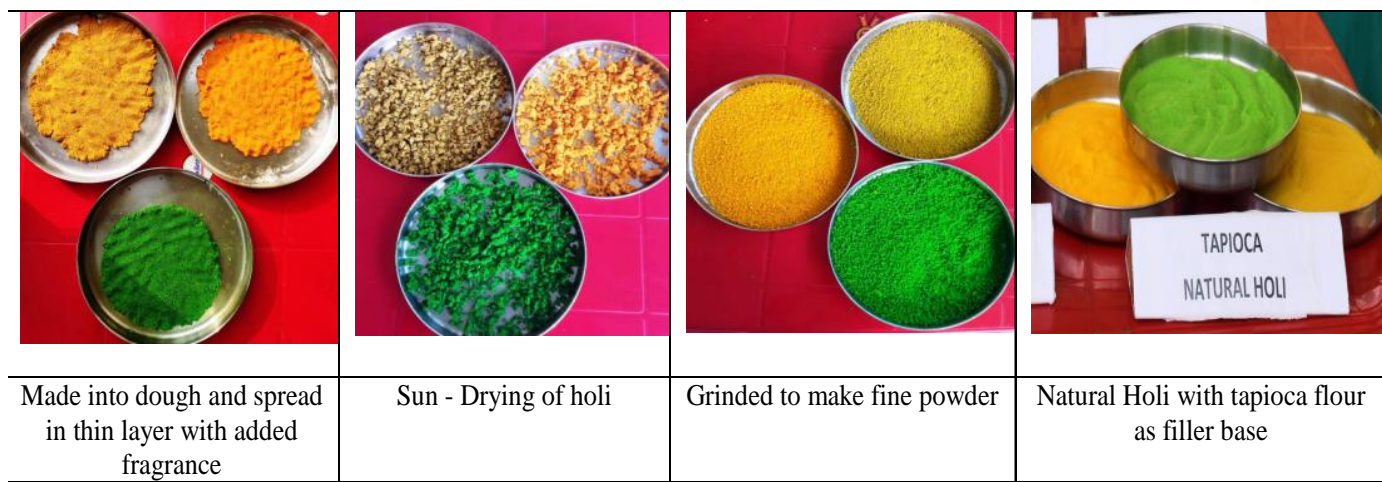

The result of colour preferences between two preferred green colour over orange and groups was shown in Fig. 2. It can be seen yellow. Similar result was observed for from the figure that most of the member members in group B. 
From overall preferences of colour, gender preference of colour was observed (Fig. 3). It was revealed that female from both the group preferred yellow colour where as male preferred green and orange colour over yellow colour. Simillarly, Birren (1952) found that men preferred orange to yellow, while women placed orange at the bottom of the list. It was also reported that men had a tendency to prefer stronger chromas than women (Plater, Unpublished Master's thesis, Indiana State College, Terre Haute, Indiana, 1967). Radeloff (1990) has found that women were more likely to have a favorite color. In expressing preferences for light versus dark colors, there were no significant differences between men and women; however, in expressing the preference for bright and soft colors, there was a difference, with women preferring soft colors and men preferring bright ones (Fig. 4).

In conclusion the present work was done to shift the focus on use of natural dye in holi, which is available plenty in nature and are beneficial for human health. Holi which is also known as "Vasant Mahotsava" as it is celebrated as the festival of harvest was once celebrated with the use of natural dye extracted from natural herbs or use of plant parts such as flower, leaves, fruit etc the festival was natural, eco friendly, non toxic to environment and human health as well. But nowadays commercial chemical holi with synthetic dye has replaced the harmless ecofriendly holi in the market. The investigation made found some toxic chemicals with some potentially severe health impacts in synthetic holi with chemical dyes. The black powders were found to contain lead oxide which can result in renal failure. The Prussian blue used in the blue powder has been associated with contact dermatitis, while the copper sulphate in the green has been documented to cause eye allergies, puffiness of the eyes, or temporary blindness. Both of the commonly used bases, asbestos or silica is associated with health issues. Lack of control over the quality and content of these colors is also a problem, as they are frequently sold by vendors who do not know their origin. From the present study, it has been observed that tapioca flour can be used as filler material for 'holi' powder making, instead of sand or soil which are presently used in commercial products. As tapioca (Manihot esculanta) is a high yielding annual crop requiring low agronomic input and it is harvested well before 'holi' (Das et al, 2015), it can be a better substitute for costly starch extracted from corn or other cereals, which are presently used in some costly herbal 'holi' powder. There is immense scope for commercial production of 'holi' powder using tapioca flour and natural dye.

\section{Acknowledgement}

We would like to record our sincere thanks and appreciation to all those who are involved in assessment of eco-friendly natural holi for proper documentation of this research paper. We would also like to acknowledge the people who are still continuing with their traditional knowledge and practices of natural dye extraction to some extent. Lastly, we would like to acknowledge all who are directly or indirectly involved by giving valuable advice, guidance and unwavering support.

\section{References}

Agarwal, A., Goel, A and Gupta, K. C. (1992). Textile Dyers and Printer. 25 (10): 28.

Ahlström, L., Eskilsson, C. S and Björklund, E. (2005). Determination of banned azo dyes in consumer goods. Trends Anal. Chem., 24 (1):49-56.

Birren, F. (1952). Your Color and Yourself, Sandusky: Prang Company Publishers, (1952).

Chaube, P., Indurkar, H and S, Moghe. S. (2010). 
Asiatic Journal of Biotechnology Resources. 1: 45-56.

Cristea, G. Y and Vilarem, S. J. (2003). Ultrasound assisted enhancement in natural dye extraction from beetroot for industrial applications and natural dyeing of leather. Ultrason. Sonochem. 16 (6): 782-789.

Das, P., Borah, A., Borah, P., and Barooah, B. (2008). Studies on local cultivar of tapioca for value addition. Regional Workshop on Accelerating growth in Horticultural Sector Challenges and opportunities for North East India. Held at AAU, Jorhat. 19-20 Aug, (2008).

Das, Priyanka., Goswami, Nani and Borah Pranjal. (2015). Development of Low cost ecofriendly 'Holi' Powder. International journal of Agriculture Innovation and research. Vol 4, Issue 3, ISSN (Online) 2319-1473.

Gardner, J. J and Lal, Deepanjali.(2012). Impact of 'Holi' on the environment: A scientific study. Archives of Applied Science Research. 4 (3):1403-1410.

Gokhale, S. B., Tatiya, A. U., Bakliwal, S. R and Fursule, R. A. (2004). Natural dye yielding plants in India. Nat Prod Rad., 3(4): 228234.

Ibrahim, S. F., Michael, M .N., Tera, F. M and Samaha, S. H. (1997). Optimisation of the Dyeing process for chemically modified cotton fabrics. Colourage. (1997): pp-27.

Kumaresan, M., Palanisamy, P. N and Kumar, P. E. (2011). Application of Eco-friendly Natural dye obtained from flower of Spathodea campanulata on silk using combination of mordants. Eur J Sci Res,. 52(3): 306-312.

Mahanta, D and Tiwari, S. C. (2005). Natural dyes yielding plants and indigenous knowledge on dye preparation in Arunachal Pradesh, North East India. Curr Sci., 88: 1474-1480.
Meyer-Warnod, B. (1984). Natural essential oils: extraction processes and application to some major oils. Perfume. Flavorist. 9: 93104.

Mohd, Yusuf (e.d). Handbook of Renewable Materials for Coloration and Finishing, (Scrivener Publishing LLC), 2018. p. 75102.

Radeloff, D. J. (1990). Role of color in perception of attractiveness. Perceptual and Motor Skills. 71: 151-160.

Rawat, V.S. (2008). Unsafe, yet holi color industry growing at $15 \%$ business standard, Lucknow India (2008).

Sarmah, A. (2013). Analysis of conscious awareness for natural color. Arch Appl. Sci. Res., 5: 273.

Sharma, A and Sexena, R. (2013). Moderation of eco friendly trends in Indian festival: Holi. Archives of applied science research. 5 (3): 129-133.

Mayuri, Tembe., Rahul, Gupta., Rahul, Bhargava and Rachna Dhaker. (2018). Yield Dependency Parameters for the Extraction of Essential Oils from different Technique, Journal of Applied Science \& Engineering Technology. 6 (Issue IV, April): 3035-3037.

Tsegaye, Fekadu., Tesfaye, Seifu and Abambagade, Abera. (2019). Extraction of Essential Oil from Orange Peel using Different Methods and Effect of Solvents, Time, Temperature to Maximize Yield. IJESC, 9 (12): 24300-24308.

Toxics Link (February 2000). The Ugly Truth behind the Colorful World Fact sheet. 8(1).

Yeh, A. I. (2004). Preparation and application of rice In: Champagne, E. T. ed. Rice: Chemistry and Technology, 3rd edn. St Paul, MN: American Association of Cereal Chemists, (2004) p, 495-540.

\section{How to cite this article:}

Puja Basumatary, Manoj Kumar Bhuyan, Porna Sarmah and Dipangka Saikia. 2021. Ecofriendly Holi using Natural Dye and Low Cost Filler Base. Int.J.Curr.Microbiol.App.Sci. 10(02): 1067-1075. doi: https://doi.org/10.20546/ijcmas.2021.1002.126 